\title{
Lambert-Eaton myasthenic syndrome
}

INSERM

\section{Source}

INSERM. (1999). Orphanet: an online rare disease and orphan drug data base. Lambert-

Eaton myasthenic syndrome. ORPHA:43393

Lambert-Eaton myasthenic syndrome (LEMS) is an autoimmune, presynaptic disorder of neuromuscular transmission characterized by fluctuating muscle weakness and autonomic dysfunction frequently associated with small-cell lung cancer (SCLC). 